\title{
A Possibility of using Antagonistic Bacterial Isolates in Controlling Fusarium Wilt of Chrysanth (Chrysanthemum sp.)
}

\author{
Ayu Sibagariang, Dwi Suryanto* and Kiki Nurtjahja \\ Department of Biology, Faculty of Mathematics and Natural Sciences, Universitas Sumatera Utara, Jalan \\ Bioteknologi No. 1, Kampus USU, Medan 20155, Indonesia.
}

\begin{abstract}
One problem faced by chrysant farmer in North Sumatera, Indonesia is to control fungal disease caused by Fusarium oxysproum. The aims of this study were to know antagonistic bacterial isolates to reduce fungal disease caused by $F$. oxysporum and to know the isolates ability in producing plant growth hormon such as indole acetic acid and in solubilizing phosphate. Eight bacterial strains, collection of Laboratory of Microbiology, Universitas Sumatera Utara were tested against $F$. oxysporum in dual culture assay. Two bacterial isolates, SP1, closely related to Bacillus amyloliquefaciens strain MPA 1034 and SP7R, closely related to Pseudomonas versuta strain L10.10 showed to reduce fusarium wilt in chrysant along with production of indole acetic acid and phosphate solubilizing properties in vitro. Application of the two antagonistic bacterial isolates resulted in considerably decrease of disease intensity caused by $F$. oxysporum. The results showed that utilization of bacterial isolate to promote chrysant performance is promising in the next future.
\end{abstract}

Keywords: Antagonistic bacteria, biological control, plant growth promoting, Chrysanthemum sp.

*Correspondence: dwisuryanto@usu.ac.id

(Received: 27 December 2018; accepted: 01 February 2019)

Citation: Ayu Sibagariang, Dwi Suryanto and Kiki Nurtjahja, A Possibility of using Antagonistic Bacterial Isolates In Controlling Fusarium Wilt of Chrysanth (Chrysanthemum sp.), J Pure Appl Microbiol., 2019; 13(1):297-305 doi: 10.22207/JPAM.13.1.32

(c) The Author(s) 2019. Open Access. This article is distributed under the terms of the Creative Commons Attribution 4.0 International License which permits unrestricted use, sharing, distribution, and reproduction in any medium, provided you give appropriate credit to the original author(s) and the source, provide a link to the Creative Commons license, and indicate if changes were made. 


\section{INTRODUCTION}

Chrysanth (Chrysanthemum sp.) is one of the most popular ornamental plants, with relatively high economic value and future marketing prospect. The domestic and foreign market demand is increasing every year (Arjana et al., 2015). One of the problems in chrysanth cultivation is fungal disease. Disease caused by Fusarium oxysporum or Fusarium wilt may render the cultivation of chrysanths in farms due to the severe disease intensities and attacks. Fusarium oxysporum is a soil-borne fungal pathogen that can survive in the soil for 8-20 years in the form of chlamydospores which are difficult to control. Mechanism of Fusarium wilt is by blocking the significant flow of water in xylem tissue of chrysanths, causing the leaves to turn yellow and wilt, and then the plants die, suffering from inadequate water and nutrients (Singh et al., 2014).

Fusarium oxysporum has been controlled using various chemical and fungicides such ethazol, benomyl, bitertanol, triadimefon, thiabenzadole, which shown effective to decrease Fusarium wilt in plants. However it may has negative effect to the environment. Crop rotation, cultivation, and sterilization are used to control the wilt disease of chrysant. Reduction of F. oxysporum with antifungal and antimicrobial properties of several plants extracts and essential oils were investigated by many workers. Inhibition of Fusarium using extract of Tagetus erecta (Riaz et al., 2008), Menthanasp (Ghorbany et al., 2010), and Lantara camera (Begum et al., 2007) were done. Treatment of plant extracts efficaciously reduced F.oxysporum.

Biological control is considered an environment-friendly approach and it has gradually replaced the application of traditional chemical pesticides to reduce environmental problem ( $\mathrm{Li}$ et al., 2017). The use of antagonistic microbes generally does not have a negative impact on the environment compared to the use of synthetic fungicides. Trichoderma (Locke et al., 1985), Penicillium sp. (Hussain et al., 2016), Alcaligenes faecalis and Bacillus cereus (Abdallah et al., 2016), and Pseudomonas fluorescens (Mohammed et al., 2011) were antagonistic microorganisms which potential as biocontrol agent for reducing Fusarium wilt in plants.
Local farmers generally perform fertilization and control of pathogenic fungi in chrysanths by using synthetic fertilizers and fungicides. The use of synthetic fertilizers and fungicides may cause soil damage, fungal resistance, resurgence, health and environment problem. An alternative to suppress Fusarium wilt is to utilise a biological control agent. This study examined two bacterial isolates SP1 and SP7R to control Fusarium wilt and to increase chrysant growth performance.

\section{MATERIALS AND METHODS}

Isolation of fungal pathogen from chrysanth

Fungal pathogens were isolated from diseased plants of relatively cold area of Brastagi, exhibiting Fusarium wilt symptoms. Plant leaves were removed, cleaned with running water, cut into $1 \mathrm{~cm}^{2}$ size, immersed in $70 \%$ ethanol for 1 minute, rinsed in sterile distilled water for 1 minute, then drained on filter paper. After drying, the sample pieces were placed on a petridish containing potato dextrose agar(PDA) medium. The culture was incubated for three days at ambient temperature until the fungal mycelium grew. The fungal colony emerging from the plant part is purified to new PDA.

\section{Identification of fungal pathogen}

Fungal pathogens were identified by using slide culture method. Isolates were inoculated at four points of block of PDA agar blocks measuring $1 \mathrm{~cm}^{2}$ on the object glass, covered with glass, and then sterile distilled water was dropped on filter paper to keep moisturity. The slide cultures were incubated for 3-4 days, then slide observed under microscope. Fungal identification was performed using standard identification book of Gilman (1975) and Pitt et al., (2009)

In vitro antagonisms of bacterial isolates against F.oxysporum causative agent of fusarium wild in chrysant

Antagonisms of bacterial isolates against F.oxysporum were observed using dual culture assay. Bacterial isolates of rhizospheric bacteria of Brassica rapa pekinensis of relatively cold area of Brastagi (SP7R, SP9R, SP11R), endophytic bacteria of Brassica rapa pekinensis (SP5E, SP4E), and aerobic bacteria from liquid waste of oil palm (SP1, SP14, SP15) of previous study were collections from Laboratory of Microbiology, Universitas 
Sumatera Utara. Mycelium of F. oxysporum was cut and inoculated in the center of a petri dish containing a medium of PDA $+3 \%$ yeast extract. A total of $10 \mu \mathrm{L}$ of bacterial suspension, each with concentration of $\approx 10^{8} \mathrm{CFU} . \mathrm{mL}^{-1}$, was inoculated into blank paper discs (Oxoid), arranged on two side of fungal culture with a distance of $1 \mathrm{~cm}$. The dual culture plates were then incubated for 7 days at amibient temperature. Inhibitory activity is indicated by the formation of inhibitory zones around the bacterial colonies towards fungal culture (Suryanto et al., 2016). Antagonism activity was further characterized microscopically by observing the mycelium at inhibitory zone of dual culture plates, showing some abnormal hyphae characteristics (Lorito et al., 1992).

Screening of plant growth promoting properties Bacterial isolates were subjected to screen for their plant growth promoting properties i.e. phosphate solubilization and production of exogenous auxinIAA. To determine phosphate solubilizing activity of isolates, Pikovskaya medium was used in this assay (Pikovskaya, 1948). The plates were inoculated with bacterial isolates and incubated for 7 days at ambient temperature. The formation of visible and clear halo zones around bacterial colonies confirmed the positive result of phosphate solubilization. To determine the production of exogenous IAA of isolates, colorimetry method was used in this assay. The assay was done as follows: three millilitres of bacterial suspension $\left(\approx 10^{8} \mathrm{CFU} \cdot \mathrm{mL}^{-1}\right)$ was inoculated into $27 \mathrm{~mL}$ Luria-Bertani broth medium, supplemented with L-tryptophan in $100 \mathrm{ml}$ flask, incubated in ambient temperature with $100 \mathrm{rpm}$ agitation. To observe the trend of IAA production in culture, sufficient volumes of broth were sampled for every $4 \mathrm{hrs}$, and centrifuged at 5500 rpm for 10 minutes. The resulting supernatants were transferred into sterile reaction tube, filled with Salkowski reagent(4:1, v/v).The mixture was incubated for 20 minutes and measured for its absorbance using a spectrophotometer at a wavelength of $530 \mathrm{~nm}$ compared to the standard curve (ppm).

In vivo antagonism of bacterial isolates against F. oxysporum

The assay was done in greenhouse. Ten millilitres of bacterial suspension $\left(\approx 10^{8}\right.$ CFU. $\mathrm{mL}^{-}$ $\left.{ }^{1}\right)$ was inoculated into 2 kilograms mixture of soil and compost in pot. A $10 \mathrm{~mL}$ of sterile distilled water without bacterial suspension were used as a control. After 7 days chrysanth seeds were planted in the pot. Inoculation of $10 \mathrm{~mL}$ per pot of $F$. oxysporum ( $\left.\mathrm{H}^{\prime \prime} 10^{6} \mathrm{CFU} \cdot \mathrm{mL}^{-1}\right)$ was done after 7 days of seed planting. Observations were conducted until 40 days including disease intensities, number of yellowing and wilting leaves, plant heights, and total number of leaves. Treatments of chrysant in pot were:

\begin{tabular}{ll}
\hline Code & Treatment \\
\hline BoFo & $\begin{array}{l}\text { No bacteria and no F. oxysporum } \\
\text { No bacteria and inoculated } \\
\text { BoFs }\end{array}$ \\
BSP1 & Bacterial isolate SP1 \\
BSP7R & Bacterial isolate SP7R \\
BSP1Fs & Bacterial isolate SP1 and F. oxysporum \\
BSP7RFs & Bacterial isolate SP7R and \\
& F. oxysporum \\
\hline
\end{tabular}

\section{Cell number counted}

One gram of soil in treatment was taken and diluted in sterile distilled water to make $10^{-}$ ${ }^{7}$ to $10^{-8}$ suspension. One $\mathrm{ml}$ of suspension was inoculated into plate count agar and incubated at $31^{\circ} \mathrm{C}$ for $24-48$ hours. Cell number was counted as colony forming unit per gram soil (CFU.g-1).

Molecular identification of potential isolates using 16S rRNA gene

Freeze-thawed method was utilised to break bacterial cell. Bacterial suspension of SP1 and SP7R in microtube was frozen at $-10^{\circ} \mathrm{C}$ and thawed at $90^{\circ} \mathrm{C}$ for 10 minutes. This was done for five times for cell-breaking efficiency. Cellbreaking solution containing DNA was used for the amplification of the 16S rRNA gene performed using PCR method with a specific primer of $63 \mathrm{f}$ (5'-CAG GCC TAA CAC ATG CAC-3) and 1387r (5'GGG CGG WGT GTA CAA GGC- 3 ') (Marchesi et al., 1998). The PCR wascarried out for 40 cycles in a Thermo Cycler (LabCycler gradient) with the initial denaturation at $94^{\circ} \mathrm{C}$ for $2 \mathrm{~min}$, cyclic denaturation at $92^{\circ} \mathrm{C}$ for $30 \mathrm{~s}$, annealing at $55^{\circ} \mathrm{C}$ for $30 \mathrm{~s}$, and extension at $72^{\circ} \mathrm{C}$ for $1 \mathrm{~min}$, with a final extension of $5 \mathrm{~min}$ at $72^{\circ} \mathrm{C}$. The PCR products were checked visually by using agarose gel electrophoresis. Purification and commercially sequencing was done to the PCR product. The sequenced data 
were checked by BLAST analysis.

\section{RESULTS}

Isolation and identification of F.oxysporum causative agent of fusarium wild in chrysant

Eight isolates P1, P2, P3, PD1C, PD2, PD3,

PD4, and PDX of potential fungal pathogens were isolated from diseased chrysanths were.One strain, P3 was further identified as F.oxysporum based on morphological characters. This isolate $d$ showed white mycelium with pinkish or purplish center of colonies. Microscopy observation confirmed that 'P3 showed to have microconidia, and an ovalshaped, elongated, and septate macroconidia (Fig. 1). The confirmation of strain P3 as F.oxysporum was also compared to characteristics described by Pitt et al., (2009) and Gilmann (1975).

Dual culture assay on antagonistic bacterial isolates against F.oxysporum

Four bacterial isolates SP1, SP5E, SP7R, and SP9R showed to inhibit F.oxysporum growth (Fig. 2). It showed that bacterial isolates varied in inhibiting fungal growth (Table 1 ). The varying degree of antagonism among isolates were assumed due to differences in production of antimicrobe substancies such as extracellular hydrolytic enzymes chitinase and glucanase into the dual culture medium. Fungal cell walls are mainly composed of chitin (4-9\% of dry weight), followed by other component of 1,3-glucans. These polymers are the main target of hydrolytic enzymes of antagonistic bacteria (Benhamou et al., 1990; Rajarathnam et al., 1998). Suryanto et al.(2011) also stated that effectiveness of antagonistic bacteria in inhibiting fungal pathogens was affected by composition of fungal cell walls, differences in growth rate between bacteria and fungi, and competing metabolites produced by bacteria to attack fungi.

Antagonistic activity of antagonistic bacteria against $F$. oxysporum was observed through microscopical examination of abnormal hyphae. The antagonistic activity of four bacterial isolates caused F.oxysporum hyphae to develop abnormal growth such as stunted, curved, distorted, lysed, and dwarf hyphae when compared to normal hyphae (Fig. 3). Inhibition of fungal growth by antagonistic bacteria was shown by the inhibition zone around fungal radial growth. The fungal mycelium did not increase in length hence the tip of the mycelium looks short and flat. The abnormalities of the hyphae were assumed to be caused by hydrolytic enzymes produced by antagonistic bacteria within inhibition zones. Meanwhile the results of the research Asnita et al., (2012) stated that the antagonistic activity of chitinolytic bacteria causes F.oxysporum hyphae to be damaged, lysed, distorted and curve. According

Table 1. Inhibition zone produced by antagonistic bacteria against $F$. oxysporum

\begin{tabular}{lc}
\hline Isolates & $\begin{array}{c}\text { Inhhibition } \\
\text { zone }(\mathrm{mm})\end{array}$ \\
\hline SP7R & 7.0 \\
SP9R & 5.5 \\
SP11R & 0 \\
SP5E & 3.30 \\
SP4E & 0.00 \\
SP1 & 15.5 \\
SP14 & 0 \\
SP15 & 0 \\
\hline
\end{tabular}

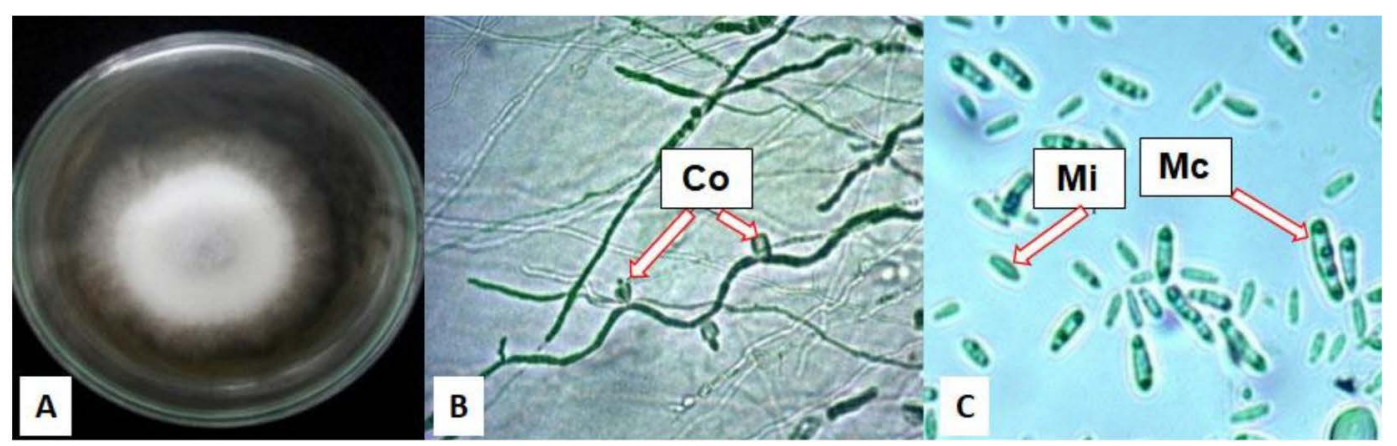

Fig. 1. F. oxysporum isolated from unhealthy chrysant. (A). Colony on PDA medium after 7 incubation days at $29^{\circ} \mathrm{C}$, (B). Hypha with conidiospore (Co), (C). Microconidia (Mi) and Macroconidia (Ma) 


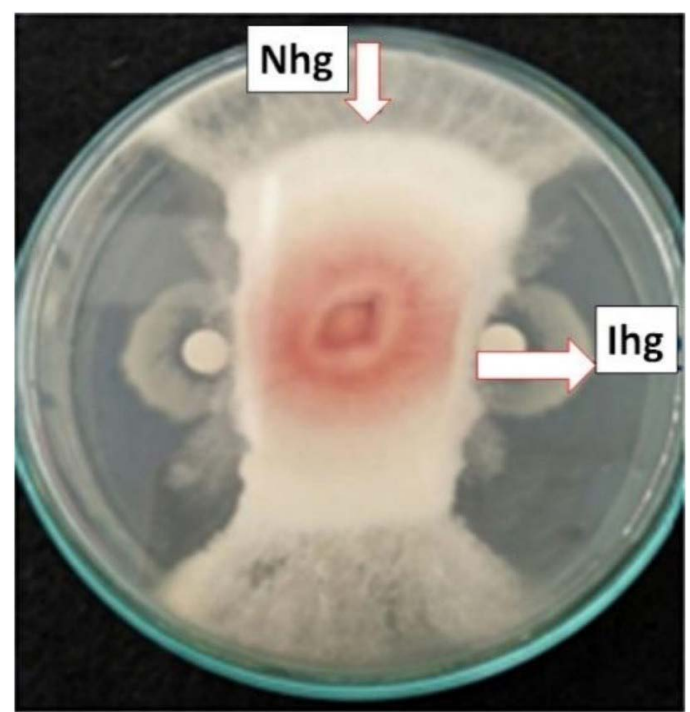

Fig. 2. Antagonistic assay of SP1 to F. oxysporum (Nhg: normal hyphae growth; Ihg: inhibited hyphal growth)

to Gohel et al., (2005), the amount of bacterial chitinase and glucanase will increase when pathogenic fungi attack. Both enzymes attack the cell wall causing hypha lysis, fragmentation and fungal hypha growth is inhibited. Chitinase enzyme is a hydrolytic enzyme that can hydrolyze $\beta-1,4$ bonds between $\mathrm{N}$-acetylglucosamine subunits in chitin polymer. Damage to chitin polymer which is an important component of the cell wall of fungal hyphae can inhibit hyphae growth.

\section{Plant growth promoting properties of antagonistic bacterial isolates}

Four antagonistic bacteria were subjected to phosphate solubilization assay in agar medium supplemented with insoluble tricalcium phosphate on Pikovskaya medium. The four isolates showed different ability in solubilizing phosphate as shown in Table 2. The formation of halo zones around colonies indicated the synthesis of extracellular organic acids which are able to bind ion $\mathrm{Ca}^{3+}$ bound into insoluble form of $\mathrm{Ca}_{3}\left(\mathrm{PO}_{4}\right)_{2}$ and free the ion $\mathrm{H}_{2} \mathrm{PO}_{4}$, forming a more clear zone than surrounding zone with bound $P$ element in agar medium (Awais et al., 2017). Another mechanism to solubilize bound $\mathrm{P}$ element is by producing extracellular phosphatase that enzymatically hydrolyze $P$ from its bound compounds (Parhamfar et al., 2016). Both mechanism is triggered genetically in which may explain the different ability among bacteria in effectively utilizing phosphate in environment (Khan et al., 2009).

Two bacterial isolates SP1 and SP7R capable to solubilise phosphate were chosen and subjected to IAA production assay. It was shown that SP7R produced more IAA copared to that of SP1 in 24 hrs of incubation. Higher production of IAA demonstrated during late logarithmic and early stationary phase of bacterial growth. Ji et al. (2014) reported the yield of IAA reaching 24.6 ppm during stationary phase of ten bacterial strains used in their study. Limited nutrients and

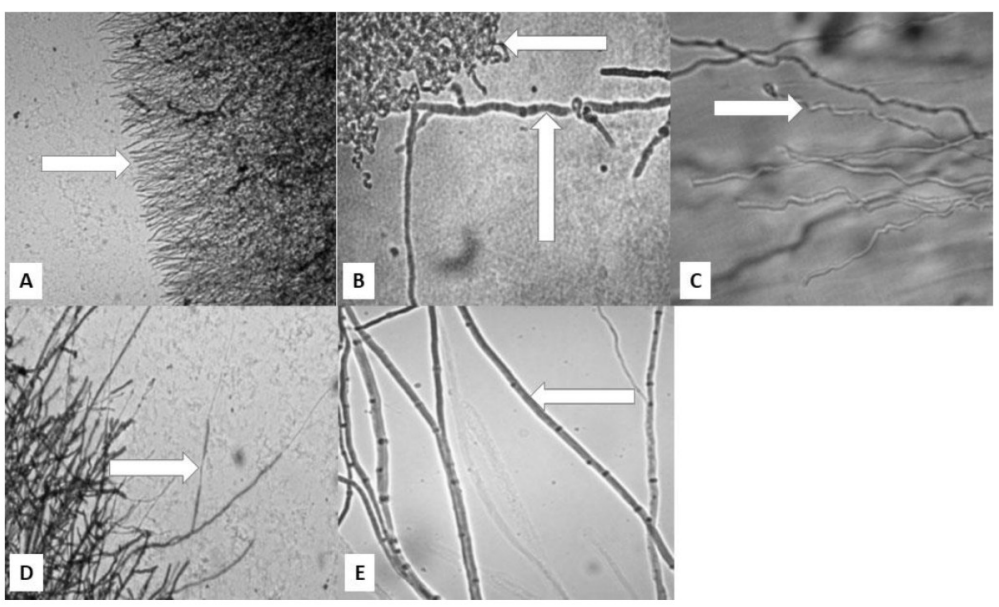

Fig. 3. Microscopical image of hyphal abnormalitiesshowed by arrow: A. stunted, B. curved, C. distorted, D. lysed and dwarfed, and E. normal hyphae. 
low $\mathrm{pH}$ contributed to transcription of certain genes involved in catalysis of potential intermediet compounds into IAA. Addition of L-tryptophan into medium may also enhance synthesis of IAA (Spaepen et al., 2007). Our result might be considered higher due to the nature of bacterial isolate used in this assay. SP7R sampled from rhizosphere of B.rapa pekinensis showed to have high IAA production in this study. Rhizospheric bacteria are known as potential IAA producers because of their interaction with plant roots. Plant roots secrete exudates such as L-tryptophan to bacteria, in order to enhance the root growth by incorporating exogenous IAA synthesized by rhizospheric bacteria into plant (Khalid et al., 2004; Rosenblueth et al., 2008).

In vivo antagonism of two selected antagonistic bacterial isolates against F.oxysporum

It was observed that treated chrysanth

Table 2. Plant growth promoting ability produced by antagonistic bacteria against $F$. oxysporum

\begin{tabular}{lcc}
\hline Isolates & $\begin{array}{c}\text { Plant Growth Promoting } \\
\text { Properties }\end{array}$ \\
\cline { 2 - 3 } & $\begin{array}{c}\text { Phosphate } \\
\text { Solubilization } \\
\text { Index }\end{array}$ & $\begin{array}{c}\text { IAA } \\
\text { Production } \\
\text { (ppm) }\end{array}$ \\
\hline SP7R & 0.96 & 83.50 \\
SP9R & 0.75 & - \\
SP11R & 0 & - \\
SP5E & 0.62 & - \\
SP4E & 0 & - \\
SP1 & 0.49 & 23.33 \\
SP14 & 0 & - \\
SP15 & 0 & - \\
\hline
\end{tabular}

Table 3. Bacterial cell number among treatments before and after application

\begin{tabular}{lcc}
\hline Treatments & \multicolumn{2}{c}{$\begin{array}{c}\text { Number of cell densities } \\
\text { (CFU.g }{ }^{-1} \text { ) }\end{array}$} \\
\cline { 2 - 3 } & $\begin{array}{c}\text { Before } \\
\text { application }\end{array}$ & $\begin{array}{c}\text { After } \\
\text { application }\end{array}$ \\
\hline B0 & $7.0 \times 10^{7}$ & $1.2 \times 10^{8}$ \\
BOFS & $9.0 \times 10^{8}$ & $9.0 \times 108$ \\
BSP1 & $1.7 \times 10^{8}$ & $5.2 \times 10^{13}$ \\
BSP7R & $1.1 \times 10^{8}$ & $3.6 \times 10^{13}$ \\
BSP1FS & $9.0 \times 10^{7}$ & $2.9 \times 10^{13}$ \\
BSP7RFS & $1.4 \times 10^{8}$ & $3.7 \times 10^{13}$ \\
\hline
\end{tabular}

with antagonistic bacteria did not show any Fusarium wilt symptoms during 40 days of planting as compared to that of $(+)$ control, chrysant infested with fungal conidia (Fig. 4). Overall profile of plant parameters in terms of plant height and number of leaves were also improved in general (Fig. 5 and 6). Other studies have reported the potential of antagonistic bacteria in treating F.oxysporum infection in several plants. Paenibacillus sp. 300 and Streptomyces sp. 358 were reported to reduce Fusarium wilt on cucumber plants (Singh et al., 1999). Other study reported the potential of three antagonists, Streptomyces setonii, Bacillus cereus, and Serratia marcescens to reduce Fusarium wilt symptoms in the stem of tomato plants by F.oxysporum (Ferraz et al., 2014). Other factor besides hydrolytic enzymes produced by antagonistic bacteria in reducing Fusarium wilt were siderophores, cyanide, and antibiotics (Cantelan et al., 1999). Those products may be evaluated in future study to gain deeper

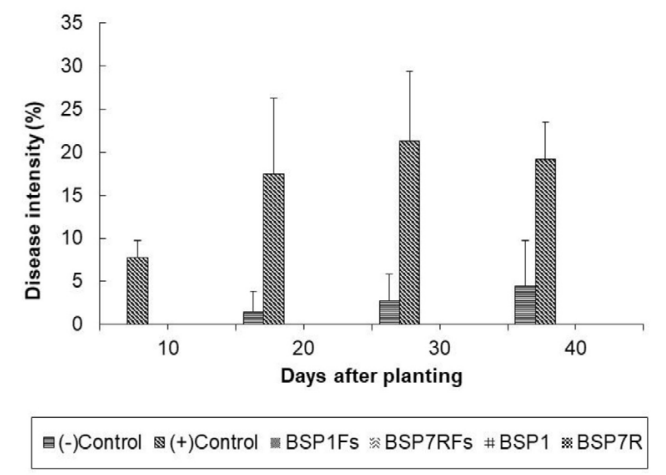

Fig. 4. Profile of disease intensity of Fusarium wilt among treated plants

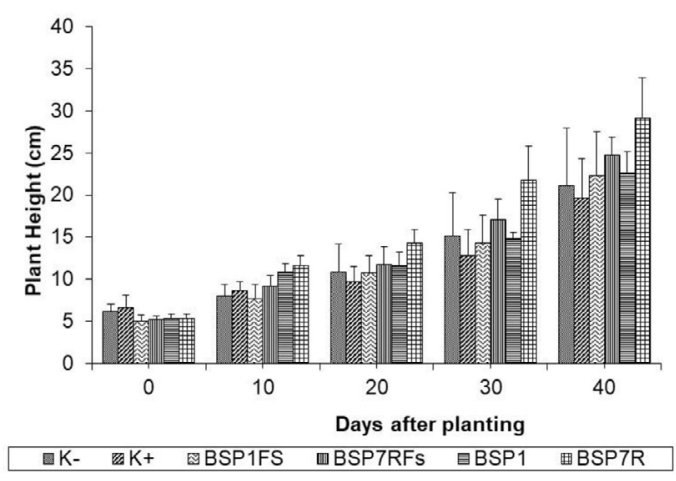

Fig. 5. Profile of plant height among treated plants 
understanding of antagonistic mechanisms from our isolates.

It showed that SP7R increased more plant performance rather than that of SP1. The ability of SP7R to improve plant growth seemed correlating with high production of IAA. Bacterial strains capable of producing IAA might accelerate the growth of plants (Bolero et al., 2007). Several IAA-producing bacteria such as Acinetobacter, Alcaligenes, Arthrobacter, Azospirillium, Azotobacter, Bacillus, Beijerinckia, Burkholderia, Enterobacter, Erwinia, Flavobacterium, and Rhizobium were reported (Esitken et al., 2010). IAA functions as essential signal molecule to regulate plant growth, such as accelerating root growth, increasing resistance against pathogens, with final outcome on overall plant growth promotion (Shaharoona et al., 2006). Chrysant growth might also be supported by phosphate solubilization ability from isolates to provide sufficient plant needs of nutrients (Thakuria et al., 2004).

\section{Bacterial cell number in pot soil}

Bacterial cell number after 40 days of planting reached $\approx 10^{13} \mathrm{CFU}^{-1} \mathrm{~g}^{-1}$ (Table 3 ). This could be assumed that bacterial cell of SP1 and SP7R survived in all treatment pots and tend to thrive in the soils. Hence, cell densities between BSP1-BSP7R (promoting groups) and BSP1FRBSP7RFS (antagonistic groups) did not differ. The abundance of soil organic matters in soil might support growth of most soil bacteria until reaching adequate cell number to execute their phenotypic roles in nutrient cycling and niches.

Molecular identification of antagonistic bacterial isolates based on their 16S rRNA gene

Two bacterial isolates, SP1 and SP7R

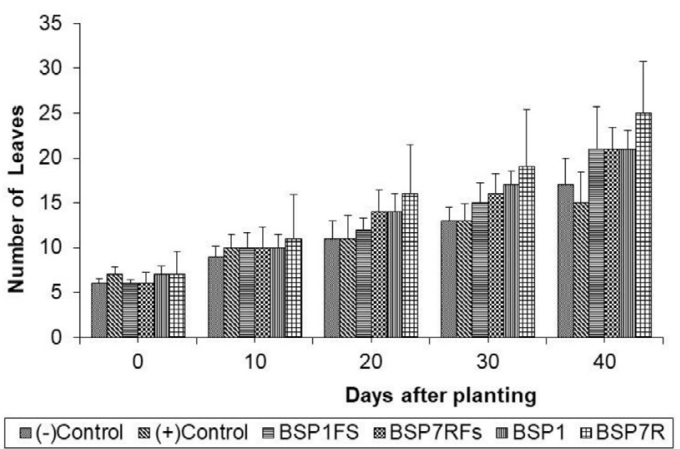

Fig. 6. Profile of number of leaves among treated plants were choosen to be identified. Isolation of gene fragment, 16S rRNA, followed by amplification in PCR using primers $63 \mathrm{f}$ and $1387 \mathrm{r}$ for 40 cycles, was successfully done. Sequence analysis using Basic Local Alignment Search Tool (BLAST) using database of $16 \mathrm{~s}$ rRNA genes, showed considerable similarity of SP1 and SP7R toBacillus amyloliquefaciens MPA 1034 by $90 \%$ and to Pseudomonas versuta $L 10.10$ by $99 \%$, respectively.

Arias et al. (2009) reported that $B$. amyloliquefaciens was a promising biocontrol agent and plant growth promoting bacteria based on genetic and biochemical characteristics. Application of $B$. amyloliquefaciens in reducing severity of plant diseases and controlling microbial pathogens was reported in several plant disease in several plant species such as bacterial wilt caused by Ralstonia solanacearum in tobacco plants, fruit rot caused by Botryosphaeria berengeriana in pear, and stem rot caused by Sclerotinia sclerotiorum in canola plants (Pingping et al., 2007; Wu et al., 2014; Wu et al., 2016). The bacteria had ability to synthesize antifungal lipopeptides, volatile organic compounds, and cell wall degrading enzymes (Wu et al., 2014). In this study, newly isolated P.versuta of relatively cold area of Brastagi for the first time was reported as biocontrol agent or plant growth promoting bacteria. The species was described as novel species by See-too et al., (2017), isolated from Antarctic soil. The prospect on evaluating further characteristics of both isolates as biocontrol and plant growth promoting agents is still needed for field application and deeper understanding of their natures.

\section{DISCUSSIONS}

Antagonistic bacteria can be used as an alternative to control plant diseases and to increase plant growth. The ability of antagonistic bacteria to inhibit the growth of plant pathogenic fungi is thought to be due to their ability to produce chitinase and glucanase. According to Adams (2004), Chitinase and glucanase are hydrolase enzymes that can hydrolyze chitin and $\beta$-glucan which are the main components of fungi cell walls. Hydrolysis of chitin and $\beta$-glucan in the walls of fungi cells can reduce the integrity of the walls of fungal cells so that they cannot infect plants. Chitinase and 1.3 glucanase are enzymes that are key to inhibiting the growth of fungi. 
Bacteria can increase plant growth by dissolving phosphate and producing IAA. Phosphorus $(\mathrm{P})$ is one of the nutrients that are important for plant growth, but its availability is very low in the soil because most phosphorus is bound by calcium ( $\mathrm{Ca}$ ) and magnesium $(\mathrm{Mg})$ in calcareous soils and by iron ( $\mathrm{Fe}$ ) and aluminum (Al) in acidic soils, so there is very little available in plants (Liu et al. 2015), therefore phosphate solubilizing bacteria are needed in increasing the availability of phosphorus $(P)$ in plants.

The ability of phosphate dissolving bacteria is related to the enzyme phosphatase and organic acids synthesized by these microorganisms. The phosphatase enzyme can decide which phosphate is bound by organic compounds to be the form available to plants. The presence of organic acids can directly dissolve phosphate which is the result of changes in $\mathrm{PO}^{3-}$ anions by acid anions or the binding of $\mathrm{Fe}$ and $\mathrm{Al}$ ions which previously bind $P$ elements so that they can release phosphates which are bound and can be absorbed by plants (Khan et al. 2009). Meanwhile, the ability of bacteria to produce auxin depends on the phase of bacterial growth and the production of auxin is usually maximal in the stationary phase (Ji et al. 2014)

The direct mechanism of bacteria in increasing plant growth includes producing growth hormones, auxin, cytokinin, gibberellins, inhibiting the production of ethylene hormones, solubilizing phosphate, and nitrogen fixation. Plant growth is increased indirectly by bacteria through its ability to produce antimicrobial pathogens, siderofors and enzymes that can suppress the growth of fungi that cause plant diseases (Esitken et al. 2010).

\section{CONCLUSION}

Eight bacterial strains, collection of Laboratory of Microbiology, Universitas Sumatera Utara were tested against F.oxysporum in dual culture assay. Two bacterial isolates SP1 and SP7R closely related to Bacillus amylolique-faciens strain MPA 1034 and to Pseudomonas versuta strain L10.10 reduced fusarium wilt in chrysant. They produced indole acetic acid and capable to solubilise phosphate in vitro. Application of the two antagonistic bacterial isolates resulted in considerably decreased of disease intensity caused by F.oxysporum and increased chrysant performance.

\section{ACKNOWLEDGMENTS}

We would like to express our deep appreciation to Universitas Sumatera Utara for partly supporting this study.

\section{CONFLICTS OF INTEREST}

The author declares that there are no conflict of interest.

\section{REFERENCES}

1. Adams DJ, Fungal cell wall chitinases and glucanases. Microbiology., 2004; 150: 2029-2035.

2. Abdallah R, Mokni S, Nefzi A, Khiareddine $H$, Remadi $\mathrm{M}$, Biocontrol of Fusarium wilt and growth promotion of tomato plants using endophytic bacteria isolated from Nicotiana galuca organs.Biological control, 2016; 97(5): 80-88

3. Arias A, Ongena M, Halimi B, Lara $Y$, Brans A, Joris B.Bacillusamyloliquefaciens GA1 as a source of potent antibiotics and other secondary metabolites for biocontrol of plant pathogens. Microbial. Cell Factories, 2009; 8(63): 1-12.

4. Arjana I, Situmeang Y, Suaria I. Study of development potential Chrysanthemum in Buleleng Regency. International journal on advanced science enginering information technology, 2015; 5(5): ISSN:2088-5334.

5. Asnita N, Sihombing S, Maimunah S, Nurtjahja K, Suryanto D.Inhibition of fungal growth isolated from three economic plants of north sumatra by chitinolytic bacterial isolates. Bulletin of Environment Pharmacology and life sciences, 2012; 1(6): 35-41

6. Awais M, Tariq M, Ali A, Ali Q, Khan A, Tabassum B, Nasir I, Husnain T. Isolation characterization and interrelationship of phosphate solubilizing bacteria from the rhizosphere of sugarcane and rice.Biocatalysis and Agricultural Biotechnology, 2017; 11(4):312-321.

7. Begum J, Yusuf M, Chaudhary J U, Khan S, Anwar M.N.Antifungal activity of forty higher plants against phytopathogenic fungi.Bangladesh Journal of Microbiology, 2007; 24: 76-78.

8. Benhamou N, Joosten MHAJ, De Wit PJGM. Subcellular localization of chitinase and of its potential substrate in tomato root tissues infected by Fusariumoxysporum f.sp.radicis-lycopersici. Plant Physiol, 1990; 92: 11081120.

9. Bolero L, Perrig D, Masciarelli O, Penna C, Cassan F, Luna V. Phytohormone production by three strains of Bradyrhizobiumjaponicumand possible physiological and technological implications. Appl. Microbiol. Biotechnol., 2007; 74(8): 874-880.

10. Cantelan AJ, Hartel PG, Fuhrmann JJ. Screening for plant growth-promoting rhizobacteria to promote early soybean growth. Soil Sci.Soc.Am., 1999; J63(10): 1670-1680.

11. Esitken A, Yildiz HE, Ercisli S, Donmez MF, Turan M, Gunes A. Effect of plant growth promoting bacteria 
(PGPB) on yield, growt hand nutrient contents of organically grown strawberry. Sci. Hort., 2010; 5(12): 62-66.

12. Ferraz H, Resende S, Silveira P, Andrade C, Milagres E, Oliveira J, Rodrigues F. Rhizobacteria induces resistance against Fusarium wilt of tomato by increasing the activity of defense enzymes. Bragantia Campinas, 2014; 73(3): 274-283

13. Ghorbany M, Jafarpour B, Rastegar M F. Application of some plant products on control of Fusarium oxysporum f sp.cumini causing cumin wilt. J. Plant. Protection, 2010; 24: 34-37.

14. Gilman JC.A Manual of Soil Fungi. Lowa State College Press, Ames, 1975.

15. Gohel V, Singh A, Vimal M, Ashwini P, Chhatpar HS. Bioprospecting and antifungal potential of chitinolytic microorganisms. Afr. J. Biotechnol., 2006; 5(2): 54-72.

16. Ji S, Gururani M, Chun S.Isolation and characterization of plant growth promoting endophyticdiazotrophic bacteria from Korean rice cultivars. Microbial. Research, 2014; 169: 83-98.

17. Khalid A, Arshad M, Zahir ZA.Screening plant growth promoting rhizobacteria for improving growth and yield of wheat. J. Appl. Microbiol., 2004; 96(32): 473480.

18. Khan AA, Jilani G, Akhtar MS, Naqvi SMS, Rasheed $M$. Phosphorus solubilizing bacteria: Occurrence, mechanisms and their role in crop production. J. Agric. Biol. Sci, 2009; 1: 48-58.

19. Li P, Chen J, Zhang K, Wang H. Possible mechanisms of control of Fusarium wilt of cut chrysanthemum by Phanerochaete chryso-sporium in continuous cropping fields. Scientific report, 2017; 7: 1-10

20. Liu Z, Yuncong, Zhang S, Fu Y, Fan X, Jaimin, Patel, Zhang M. Characterization of phosphate-solubilizing bacteria isolated from calcareous soils.Applied Soil Ecology, 2015; 96: 217-224

21. Locke J, Marois J, Papavizas G. Biological control of fusarium wilt of greenhouse-grown Chrysan-themum. Plant Disease, 1985; 69(2): 167-169

22. Lorito M, Harman G.E, Hayes C.K, Broadway R.M, Tronsmo A, Woo S.L, Di Pietro A. Chitinolytic enzymes produced by Trichoderma harzianum: antifungal activity or purified endochitinase and chitobiosidase. Phytopathol, 1993; 83(3): 313-318

23. Marchesi JR, Sato T, Weightman A, Martin TA, Fry JC, Hiom S, Wade W. Design and evaluation of useful bacterium-specific PCR primers that amplify genes coding for bacterial $16 \mathrm{~S}$ rRNA. Applied and Environmental Microbiology, 1998; 64(2): 795-799

24. Mohammed A, Ani L, Bekbayeva, Salleh B. Biological control of Fusarium oxysporum by Pseudomonas fluorescens and BABA in Vitro. World Applied Sciences Journal, 2011; 15(2): 189-191

25. Parhamfar M, Dalfard A, Rad S. Purification and characterization of an extracellular phosphatase enzyme fromBacillus spp.Journal of Cell and Molecular Research, 2016; 8(2): 90-97.

26. Pikovskaya RI. Mobilization of phosphorus in soil connection with the vital activity of some microbial species.Microbiologiya, 1948; 17: 362-370.

27. Pingping $S$, Jianchao $C$, Xiaohui J, Wenhui W. Isolation and characterization of Bacillus amyloliquefaciens L-1 for biocontrol of pear ringrot.Horticultural Plant Journal, 2017; 3(5): 183-189.

28. Pitt J, Hocking A. Fungi and Food Spoilage. Springer Dordrecht Heidelberg. London, 2009.

29. Rajarathnam S, Shashriekha MNJ, Bano Z. Biodegradative and biosynthetic capacities of mushrooms: Present and future strategies. Crit. Rev. Biotech., 1998; 18: 91-236.

30. Riaz T, Khan S.N.and Javaid A. Antifungal activity of plant extract against Fusarium oxysporum the cause of corm rot of Gladiolus. Mycopathology, 2008; 6: 13-15.

31. Rosenblueth $M$, Martonez-Romero E. Bacterial endophytes and their interactions withhosts.The American Phytopathological Society. MPMI, 2006; 19(8): 827-837.

32. See-Too WS, Salazar S, Ee R, Convey P, Chan K, Peix A. Pseudomonasversuta sp. Nov., isolated from Antarctic soil.Systematic and Applied Micro-biology, 2017; 40(4): 191-198.

33. Shaharoona B., M.Arshad, Z. A. Khalid. Performance of Pseudomonas spp. containing ACC-diaminase for improving growth and yield of maize (Zea mays L.) in the presence of nitrogenous fertilizer. Soil Biol. Biochem., 2006; 38(10): 2971-2975.

34. Singh PP, Shin YC, Park CS, Chung YR. Biological control of Fusarium wilt of cucumber by chitinolitic bacteria. Phytopathology, 1999; 89(43): 92-99.

35. Singh PK, Kumar V.Fusarium wilt of Chrisanthemumproblem and prospect. Plant Pathology \& Quarantine, 2014; 4(1): 33-42.

36. Spaepen S, Venderleyden J, Remans R. Indole-3-acetic acid in microbial and microorganism-plant signaling. FEMS Microbiol., 2007; Re31(4): 425-448.

37. Suryanto D, Irawati N, Munir E. Isolation and characterization of chitinolytic bacteria and theirpotential to inhibit plant pathogenic fungi. Microbiol. Indones., 2011; 5(3): 144-148.

38. Suryanto D, Yeldi N, Munir E. Antifungal activity of endophyte bacterial isolates from torch ginger (Etlingera elicitor (Jack.) RM Smith) root to some pathogenic fungal isolates. International Journal of Pharm. Tech. Research, 2016; 9(8): 340-347.

39. Thakuria DN, Talukdar C, Goswami C, Hazarika S, Boro RC, Khan MR. Characterization and screening of bacteria from rhizosphere of rice grown in acidic soils of assam. Current Sci., 2004; 86(25): 978-985.

40. Wu Y, Yuan J, Raza W, Shen Q, Huang Q. Biocontroltraits and antagonisticpotential of Bacillus amyloliquefaciens Strain NJZJSB3 against Sclerotiniasclerotiorum, a causalagent of canolastem rot. J. Microbiol. Biotechnol., 2014; 24(10): 1327-1336.

41. Wu B, Wang $X$, Yang L, Yang H, Zeng H, Qiu Y, Wang C. Effects of Bacillus amyloliquefaciens ZM9 on bacterial wilt and rhizosphere microbial communities of tobacco. Applied Soil Ecology, 2016; 103: 1-12. 